\title{
Evaluation of Daytime Sleepiness in Hypothyroid Patients
}

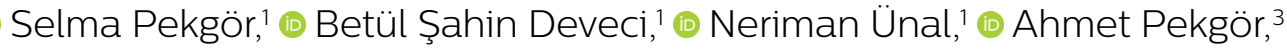 \\ (1) Cevdet Duran, ${ }^{2}$ (1) Yasemin Alagöz, ${ }^{1}$ (1) Mehmet Ali Eryılmaz'
}

\begin{abstract}
'Department of Family Medicine University of Health Sciences, Konya Training and Research Hospital Konya, Turkey

${ }^{2}$ Department of Endocrinology and Internal Medicine, Uşak University Faculty of Medicine, Uşak, Turkey ${ }^{3}$ Department of Statistics, Necmettin Erbakan University Faculty of Science, Konya, Turkey

Submitted: 20.08 .2019 Accepted: 30.09 .2019
\end{abstract}

Correspondence: Selma Pekgör, Sağlık Bilimleri Üniversitesi, Konya Eğitim ve Araştırma Hastanesi, Aile Hekimliği Kliniği, Konya, Turkey E-mail: selmapekgor@outlook.com

\begin{tabular}{r}
\hline \\
Keywords: Epworth \\
sleepiness scale; excessive \\
daytime sleepiness; \\
hypothyroidism. \\
Co $\mathbf{0}$ \\
Atribution-Noncommercial 4.0 International License.
\end{tabular}

\begin{abstract}
Objective: The present study aims to investigate the excessive daytime sleepiness in patients with hypothyroidism and in the healthy control group using the Epworth sleepiness scale.

Methods: This study was completed with 127 people, 75 of whom were hypothyroidism and 52 were control group. Age, height, weight, body mass index, waist circumference, systolic and diastolic blood pressure of the all participants were recorded. Thyroid hormone tests and biochemical parameters were examined in the morning. Epworth Sleepiness Scale was used to measure daytime sleepiness.
\end{abstract}

Results: Epworth Sleepiness Scale scores were $7.3 \pm 0.7$ in the hypothyroid group and $6.4 \pm 0.4$ in the control group, and there was no significant difference between the groups $(p=0.703)$. Weight $(p<0.00 \mathrm{I})$, body mass index $(p<0.00 \mathrm{I})$, waist circumference $(p=0.00 \mathrm{I})$ and triglyceride levels $(p=0.00 \mathrm{I})$ were higher and high density lipoprotein levels were lower $(p=0.00 \mathrm{I})$ in the hypothyroid group than the control group. Total cholesterol, low density lipoprotein level and high density lipoprotein level were lower in patients with hypothyroidism and excessive daytime sleepiness than those without hypothyroidism. High density lipoprotein levels were also lower in the group with normal thyroid function and excessive daytime sleepiness. There was no correlation between Epworth Sleepiness Scale scores and age, weight, height, body mass index, waist circumference, neck circumference, thyroidstimulating hormone, systolic and diastolic blood pressure and blood lipid levels ( $p>0.05)$.

Conclusion: Hypothyroidism and control group were similar concerning excessive daytime sleepiness. However, metabolic parameters deteriorated in daytime sleepy group compared to non-daytime sleepy group. It was concluded that similar studies with broader participation should be conducted.

\section{INTRODUCTION}

Hypothyroidism is called the clinical picture that develops as a result of insufficient secretion of thyroid hormones. [1] The most common causes of hypothyroidism are iodine deficiency in severe iodine deficiency regions, and in other regions, it is Hashimoto thyroiditis, which is chronic autoimmune thyroiditis. ${ }^{[2]}$ The prevalence of hypothyroidism is between $1-2 \%$, and it is 10 times more common in women than in men. ${ }^{[3]}$

Thyroid hormones affect and regulate all major metabolic pathways. ${ }^{[4]}$ Signs and symptoms in hypothyroidism are revealed as a result of slowing of metabolic events that arise from thyroid hormone deficiency and accumulation of glucosaminoglycans in interstitial tissue. The most common symptoms and signs are dry skin, easily catching cold, fatigue and constipation. More rarely, weight gain, hair loss, forgetfulness, decreased concentration, loss of appetite, depression, and menstrual irregularities are observed. In cases with severe hypothyroidism, pericardial and pleural effusion, carpal tunnel syndrome, sleep apnea and galactorrhea may be seen. ${ }^{[2]}$

Excessive Daytime Sleepiness (EDS) is the most common type of sleep disturbance and is generally assumed to occur as a result of disturbed or inadequate sleep. EDS is defined as an irresistible sleepiness in an individual who is expected to remain awake and alert. ${ }^{[5]}$ Patients with EDS are likely to fall asleep even when they need to stay awake and concentrated, such as during driving, doing sports or walking outside. ${ }^{[6]}$ People with EDS may experience lifethreatening road or work accidents, social incompatibility, a decrease in academic or professional performance. ${ }^{[7]}$ The most common causes of EDS are incompliance to sleep hygiene, chronic insomnia,drugs, physical and psychiatric conditions and sleep disorders as obstructive sleep apnea and narcolepsy, as well. ${ }^{[7]}$ 
EDS has been shown to be associated with obesity, diabetes, insulin resistance, age, shift work, stress, insomnia, anxiety, and depression. ${ }^{[8-16]}$ Being a woman, alcohol consumption, history of physical disorder and suicidal ideation were identified as independent risk factors. ${ }^{[16]}$ Besides, some studies have shown that EDS is the main sign of respiratory sleep disorders, while others have demonstrated that this relationship is a weak one. ${ }^{[1,17]}$ When evaluating a patient with EDS, it is necessary to consider possible risk factors. In this study, we aimed to evaluate EDS in patients with hypothyroidism.

\section{MATERIALS AND METHODS}

Between March 2016 and March 2017, a total of 127 people, including 75 patients who were diagnosed with hypothyroidism and 52 control subjects, who were admitted to the outpatient clinics of the departments of the family medicine and endocrine and metabolic diseases of our hospital, were included in this study. Diagnosis of hypothyroidism was considered when TSH was $>10 \mu \mathrm{lU} / \mathrm{mL}$ or between 4-9.9 $\mu \mathrm{lU} / \mathrm{mL}$ while free T4 was $<0.89 \mathrm{ng} / \mathrm{mL}$. In the study, a control group was formed from healthy individuals with normal free T4 levels, and TSH levels between 0.5 and $3.99 \mu \mathrm{lU} / \mathrm{mL}$. The average age of both groups was equalized. Physical examination findings and height, weight, waist circumference, waist circumference, systolic and diastolic blood pressure of the patients measured by the researchers were recorded. Body mass indices (BMls) of the participants were calculated by dividing their weight in kilograms by the square of the height in meters.

Blood samples were taken from the study participants in the morning after 12 hours of fasting for biochemical and hormone tests. Venous blood samples were taken from the left arm to measure triglyceride (TG), high-density lipoprotein (HDL) cholesterol, low-density lipoprotein (LDL) cholesterol, total cholesterol (TC), thyroid-stimulating hormone (TSH) and free thyroxine (fT4) levels, and analyzed in the same day. HDL-cholesterol levels were measured by immune reaction (with antigen-antibody complex) using the Olympus AU 5800 instrument (Beckman Coulter Inc., CA, USA). TG levels were measured with an auto analyzer Olympus AU 5800 instrument (BeckmanCoulter Inc, CA, USA) using a routine enzymatic method. TC levels were measured with the help of the original reagent analysis method using the Abbott Architect 16000 system. LDL cholesterol levels were calculated using the Friedewald formula ( $\mathrm{TC}=\mathrm{LDL}+\mathrm{HDL}+\mathrm{TG} / 5)$. TSH and $\mathrm{TT} 4$ levels were measured by chemiluminescence method using AdviaCetaur XP (Siemens Healthcare Diagnostic, Siemens AG, Germany) kit. In addition, each patient was administered the Likert-type Epworth Sleepiness Scale (ESS), which measures the general level of daytime sleepiness. ESS contains eight questions, and each question is scored between 0-3 points. Ten points out of a total of 24 points and above shows the presence of pathological sleepiness. ${ }^{\left[{ }^{[8]}\right.}$ It is a simple, easy-to-understand, validated scale with proven validity and reliability in evaluating the general sleepiness level. The validity and reliability of ESS in our country were demonstrated by the study of Ağargün et al. ${ }^{[19]}$

Use of any drug that affects blood lipid levels, such as having previously used drugs with a diagnosis of sleep disorder, presence of postpartum or subacute thyroiditis, previous thyroid surgery, presence of malignancy, pregnancy, breastfeeding, alcohol or substance abuse, use of a lipidlowering drug and corticosteroids, were determined as exclusion criteria.

Statistical analyzes of the data obtained in this study were evaluated using SPSS 22 package program at $\alpha=0.05$ significance level. Categorical variables were expressed as frequencies and percentages; numerical variables as mean, standard error, median, min-max. Kolmogorov-Smirnov and Shapiro-Wilk analyzes were used in descriptive statistics and distributional compatibility tests in single groups. Since all data were parametric, T-test was applied in comparisons between two groups. Pearson correlation analysis was used to measure the relationship between study parameters.

\section{RESULTS}

Our study was completed with a total of 127 participants (24 (18.9\%) male, and 103 (8I.1\%) female, including 75 patients and 52 control subjects. While $76.4 \%(n=97)$ of the participants were married, $23.6 \%(n=30)$ of them were single. Mean ages of the two groups were comparable (hypothyroidism group: $39.4 \pm 1.4$ years and the control group: $39.1 \pm 1.8$ years). EDS was seen in $39.4 \%$ among all participating patients. While the rate of EDS was $34.7 \%(n=26)$ in the group with hypothyroidism, this rate was $46.2 \%$ $(n=24)$ in the control group. Any statistically significant difference was not found between both groups. In the group with hypothyroidism, weight $(p<0.00 \mathrm{I}), \mathrm{BMI}(\mathrm{p}<0.00 \mathrm{I})$, waist circumference $(p=0.00 \mathrm{I})$, TG level $(p=0.00 \mathrm{I})$ and HDL level $(p=0.001)$ were lower than the control group. There was no significant difference between the groups as for systolic and diastolic blood pressures, TG and LDL values. The ESS scores were $7.3 \pm 0.7$ in the hypothyroidism group and $6.4 \pm 0.4$ in the control group, without any significant intergroup difference $(p=0.703)$ (Table I).

The group of patients with hypothyroidism was analyzed separately as patients with and without EDS. In patients with EDS, TC $(p=0.04 I)$, LDL $(p=0.003)$ levels were higher and HDL-c $(p=0.044)$ level was lower than patients without EDS. Similarly, patients with EDS had increased body weight, BMI, waist circumference, without reaching a statistically significant level. The healthy control group without hypothyroidism was also analyzed as patients with and without EDS. In patients with EDS, body weight, BMI, waist circumference, systolic and diastolic blood pressures, TG, LDL values were higher, without reaching statistically significant levels. HDL-c levels were statistically significantly lower in patients with EDS $(p=0.004)$ (Table 2).

All participants were re-grouped as with and without EDS, including the hypothyroidism and the control groups. 
Table I. Evaluation of the study parameters between hypothyroidism and control groups

\begin{tabular}{|c|c|c|c|}
\hline & Control Group $(n=52)$ & Hypothyroidism Group $(n=75)$ & $\mathbf{p}$ \\
\hline & Mean $\pm S D$ & Mean \pm SD & \\
\hline Age (year) & $39.1 \pm 1.8$ & $39.4 \pm 1.4$ & 0.711 \\
\hline Height $(\mathrm{cm})$ & $162.6 \pm 0.97$ & $163.4 \pm 0.8$ & 0.370 \\
\hline Weight (kg) & $68.7 \pm 2.1$ & $80.3 \pm 2.1$ & $<0.001$ \\
\hline Body mass index $\left(\mathrm{kg} / \mathrm{m}^{2}\right)$ & $25.9 \pm 0.7$ & $30.1 \pm 0.8$ & $<0.001$ \\
\hline Waist circumference $(\mathrm{cm})$ & $91.9 \pm 2.8$ & $99.2 \pm 1.6$ & 0.001 \\
\hline Thyroid-stimulating hormone $(\mu \mathrm{U} / \mathrm{ml})$ & $1.76 \pm 0.12$ & $14.3 \pm 2.3$ & $<0.001$ \\
\hline Free thyroxine $(\mathrm{ng} / \mathrm{mL})$ & $1.2 \pm 0.0$ & $1.0 \pm 0.0$ & $<0.001$ \\
\hline Systolic blood pressure (mmHg) & $113.4 \pm 3.3$ & $116.3 \pm 2.7$ & 0.973 \\
\hline Diastolic blood pressure $(\mathrm{mmHg})$ & $73.4 \pm 1.7$ & $74.1 \pm 1.6$ & 0.895 \\
\hline Total cholesterol (mg/dL) & $213.9 \pm 7.6$ & $209.0 \pm 6.4$ & 0.594 \\
\hline High-density lipoprotein-cholesterol (mg/dL) & $64.8 \pm 5.8$ & $50.5 \pm 2.7$ & 0.001 \\
\hline Triglyceride (mg/dL) & $97.0 \pm 6.2$ & $162.0 \pm 19.2$ & 0.001 \\
\hline Low-density lipoprotein-cholesterol (mg/dL) & $126.5 \pm 6.4$ & $129.7 \pm 8.0$ & 0.492 \\
\hline Epworth Sleepiness Scale scores & $7.3 \pm 0.7$ & $6.4 \pm 0.4$ & 0.703 \\
\hline
\end{tabular}

SD: Standard deviation.

Table 2. Comparison of the hypothyroidism and control groups with and without EDS

\begin{tabular}{|c|c|c|c|c|c|c|}
\hline & \multicolumn{3}{|c|}{ Control Group $(n=52)$} & \multicolumn{3}{|c|}{ Hypothyroidism Group $(n=75)$} \\
\hline & $\begin{array}{c}\text { EDS (+) } \\
(n=24)\end{array}$ & $\begin{array}{l}\text { EDS (-) } \\
(n=28)\end{array}$ & $\mathbf{p}$ & $\begin{array}{c}\text { EDS (+) } \\
(n=26)\end{array}$ & $\begin{array}{l}\text { EDS (-) } \\
(n=49)\end{array}$ & $\mathbf{p}$ \\
\hline & Mean $\pm S D$ & Mean \pm SD & & Mean $\pm S D$ & Mean $\pm S D$ & \\
\hline Age (year) & $38.04 \pm 2.48$ & $40.11 \pm 2.80$ & 0.686 & $41.31 \pm 2.36$ & $38.49 \pm 1.77$ & 0.358 \\
\hline Height (cm) & $162.96 \pm 1.59$ & $162.96 \pm 1.59$ & 0.818 & $161.88 \pm 1.23$ & $164.29 \pm 1.03$ & 0.177 \\
\hline Weight (kg) & $73.04 \pm 3.69$ & $64.98 \pm 2.25$ & 0.112 & $83.73 \pm 3.60$ & $78.61 \pm 2.73$ & 0.216 \\
\hline Body mass index $\left(\mathrm{kg} / \mathrm{m}^{2}\right)$ & $27.60 \pm 1.42$ & $24.58 \pm 0.75$ & 0.147 & $31.91 \pm 1.28$ & $29.19 \pm 1.00$ & 0.095 \\
\hline Waist circumference $(\mathrm{cm})$ & $97.50 \pm 5.37$ & $87.11 \pm 2.27$ & 0.127 & $102.23 \pm 2.73$ & $97.73 \pm 2.11$ & 0.189 \\
\hline $\mathrm{TSH}(\mu \mathrm{U} / \mathrm{mL})$ & $1.73 \pm 0.16$ & $1.78 \pm 0.18$ & 0.941 & $11.90 \pm 2.19$ & $|5.6| \pm 3.48$ & 0.458 \\
\hline Free thyroxine $(\mathrm{ng} / \mathrm{mL})$ & $1.2 \pm .0$ & $1.2 \pm 0.0$ & 0.182 & $1.0 \pm 0.0$ & $0.9 \pm 0.0$ & 0.503 \\
\hline Systolic blood pressure $(\mathrm{mmHg})$ & $117.39 \pm 3.57$ & $110.00 \pm 5.44$ & 0.360 & $116.15 \pm 3.96$ & $116.49 \pm 3.67$ & 0.802 \\
\hline Diastolic blood pressure $(\mathrm{mmHg})$ & $74.78 \pm 2.66$ & $72.22 \pm 2.41$ & 0.497 & $74.23 \pm 2.89$ & $74.15 \pm 2.02$ & 0.920 \\
\hline Total cholesterol $(\mathrm{mg} / \mathrm{dL})$ & $201.17 \pm 7.84$ & $224.74 \pm 12.17$ & 0.155 & $217.27 \pm 8.09$ & $204.49 \pm 8.92$ & 0.041 \\
\hline HDL-cholesterol (mg/dL) & $50.78 \pm 2.10$ & $76.74 \pm 10.21$ & 0.004 & $52.35 \pm 2.05$ & $49.57 \pm 4.08$ & 0.044 \\
\hline Triglyceride (mg/dL) & $98.30 \pm 8.42$ & $95.89 \pm 9.14$ & 0.640 & $117.72 \pm 10.46$ & $184.69 \pm 28.17$ & 0.219 \\
\hline LDL-cholesterol (mg/dL) & $|30.73 \pm 7.8|$ & $128.82 \pm 13.45$ & 0.763 & $144.10 \pm 6.68$ & $117.29 \pm 8.99$ & 0.003 \\
\hline Epworth Sleepiness Scale scores & $12.58 \pm 0.78$ & $2.89 \pm 0.27$ & $<0.001$ & $1 \mathrm{I} .42 \pm 0.53$ & $3.88 \pm 0.29$ & $<0.001$ \\
\hline
\end{tabular}

There was no significant differences between groups with and without EDS as for age, height, body weight, BMI, waist circumference, neck circumference, systolic and diastolic blood pressures, TSH, total cholesterol, LDL, HDL and TG values (Table 3). Correlation between study parameters was observed in all patients. No correlation was found between EDS scores and age, weight, height, BMI, waist circumference, TSH, $\mathrm{TT} 4$, systolic and diastolic blood pressures and blood lipid levels $(p>0.05)$. A positive correlation between $\mathrm{TSH}$ and TG, and a negative correlation between TSH and fT4 were found (Table 4).
Patients with EDS were grouped as patients under 30 and over 30 years of age. EDS was seen at a rate of $36.8 \%$ at the age of $\leq 30$ and at a rate of $40.4 \%$ at the age of $\geq 30$ years, there was no statistically significant difference between both groups ( $p>0.05)$.

\section{DISCUSSION}

Among the subjective diagnostic tools for EDS, the most frequently used scale is ESS. ${ }^{[7]}$ We also used ESS to evaluate daytime sleepiness in patients with hypothyroidism. The 
Table 3. Evaluation of the study parameters between groups with and without EDS

\begin{tabular}{|c|c|c|c|}
\hline & EDS $(-)(n=77)$ & $\operatorname{EDS}(+)(n=50)$ & $\mathbf{p}$ \\
\hline & Mean $\pm S D$ & Mean $\pm S D$ & \\
\hline Age (year) & $39.0 \pm 1.5$ & $39.7 \pm 1.7$ & 0.735 \\
\hline Height $(\mathrm{cm})$ & $163.6 \pm 0.79$ & $162.4 \pm 0.9$ & 0.364 \\
\hline Weight (kg) & $73.6 \pm 2.0$ & $78.6 \pm 2.6$ & 0.098 \\
\hline Body mass index $\left(\mathrm{kg} / \mathrm{m}^{2}\right)$ & $27.5 \pm 0.7$ & $29.8 \pm 0.9$ & 0.058 \\
\hline Waist circumference $(\mathrm{cm})$ & $93.8 \pm 1.6$ & $99.9 \pm 2.9$ & 0.090 \\
\hline Thyroid-stimulating hormone $(\mu \mathrm{U} / \mathrm{mL})$ & $10.5 \pm 2.3$ & $7.0 \pm 1.3$ & 0.157 \\
\hline Free thyroxine $(\mathrm{ng} / \mathrm{mL})$ & $1.1 \pm 0.0$ & $I . I \pm 0.0$ & 0.801 \\
\hline Systolic blood pressure (mmHg) & $114.1 \pm 3.0$ & $116.7 \pm 2.6$ & 0.418 \\
\hline Diastolic blood pressure $(\mathrm{mmHg})$ & $73.4 \pm 1.5$ & $74.4 \pm 1.9$ & 0.625 \\
\hline Total cholesterol (mg/dL) & $211.8 \pm 7.2$ & $209.7 \pm 5.7$ & 0.561 \\
\hline High-density lipoprotein-cholesterol (mg/dL) & $59.2 \pm 4.6$ & $5 \mathrm{I} .6 \pm \mathrm{I} .4$ & 0.992 \\
\hline Triglyceride (mg/dL) & $153.1 \pm 19.0$ & $108.4 \pm 6.8$ & 0.313 \\
\hline Low-density lipoprotein-cholesterol (mg/dL) & $121.4 \pm 7.5$ & $137.6 \pm 5.1$ & 0.050 \\
\hline Epworth Sleepiness Scale scores & $3.5 \pm 0.2$ & $11.9 \pm 0.4$ & $<0.001$ \\
\hline
\end{tabular}

EDS: Excessive daytime sleepiness; SD: Standard deviation.

Table 4. Correlation between study parameters

\begin{tabular}{|c|c|c|c|c|c|c|}
\hline & \multicolumn{2}{|c|}{ ESS } & \multicolumn{2}{|c|}{ TSH } & \multicolumn{2}{|c|}{ fT4 } \\
\hline & $\mathbf{r}$ & $\mathbf{p}$ & $\mathbf{r}$ & $\mathbf{p}$ & $\mathbf{r}$ & $\mathbf{p}$ \\
\hline Age & -0.44 & 0.615 & -0.094 & 0.258 & -0.011 & 0.900 \\
\hline Weight & 0.069 & 0.427 & 0.078 & 0.349 & -0.052 & 0.543 \\
\hline Body mass index & 0.151 & 0.080 & 0.080 & 0.337 & -0.116 & 0.176 \\
\hline Waist circumference & -0.028 & 0.764 & 0.017 & 0.837 & -0.044 & 0.608 \\
\hline Systolic blood pressure & -0.009 & 0.915 & -0.108 & 0.208 & 0.038 & 0.662 \\
\hline Diastolic blood pressure & -0.042 & 0.638 & -0.059 & 0.488 & -0.029 & 0.744 \\
\hline Total cholesterol & 0.004 & 0.964 & 0.395 & $<0.001$ & -0.090 & 0.303 \\
\hline High-density lipoprotein-cholesterol & -0.103 & 0.238 & -0.041 & 0.630 & 0.076 & 0.381 \\
\hline Triglyceride & -0.07 & 0.385 & 0.118 & 0.311 & -0.058 & 0.505 \\
\hline Low-density lipoprotein-cholesterol & -0.065 & 0.420 & 0.220 & 0.340 & -0.048 & 0.490 \\
\hline Epworth Sleepiness Scale & - & - & -0.088 & 0.311 & -0.058 & 0.505 \\
\hline Thyroid-stimulating hormone & -0.088 & 0.311 & - & - & -0.595 & $<0.001$ \\
\hline Free thyroxine & -0.058 & 0.505 & -0.595 & $<0.001$ & - & - \\
\hline
\end{tabular}

ESS: Epworth Sleepiness Scale; TSH: Thyroid-stimulating hormone; fT 4: Free thyroxine.

mean ESS scores were found to be $7.3 \pm 0.7$ in the group with hypothyroidism and $6.4 \pm 0.4$ in the control group, without any significant difference between the groups. According to the literature information we obtained, a study evaluating EDS in patients with hypothyroidism has not been performed so far. To our knowledge, our study is the first study on this subject.

The prevalence of EDS varies widely across different studies, and it is estimated to range between $10.5-62.9 \%$. In the study conducted among 382 nursing students, its incidence was determined as $10.5 \%$, in the study conducted among medical students as $26.9 \%$ and $24.6 \% .^{[16,20,21]}$ In other studies, its prevalence was found to be higher than $35.5 \% .^{[22-28]}$ In our study, this rate was determined to be $34.9 \%$.
In a study conducted by Mirghani et al. ${ }^{[26]}$ in 2015, EDS was accepted to be present when the participants had a BMI score of 9 or higher. Nevertheless, Johns, ${ }^{[29]}$ who designed this scale, accepted the ESS scores above 10 as EDS. In our study, we accepted 10 points and above as pathological sleepiness.

EDS has been reported to be more frequent in obese individuals, than non-obese individuals. ${ }^{[8,11,16]}$ In our study, body weight, BMI and waist circumference were higher in individuals with EDS, without reaching a statistically significant level.

In studies that were conducted, the incidence of EDS increases with age between the ages of $30-75 .^{[9,11]}$ In our study, the rate of EDS under the age of 30 was $36.8 \%$, and 
it was $40.4 \%$ above the age of 30 without any statistically significant intergroup difference.

A study investigating sleep disorders in patients with endstage renal failure included $\mathbf{8 8}$ end-stage renal failure patients who underwent hemodialysis three times a week. Epworth Sleepiness Scale was applied to these patients, and patients were classified according to the scores they received as patients having normal sleep patterns (0-8), mild (9-12), and moderate to severe (13-24) sleep disorders. It was found that respective percentages of the patients had normal sleep patterns (36.36\%), mild (59.09\%) and moderate to severe $(4.54 \%)$ sleep disorders. In this study, it was shown that the only external factor that plays a role in sleep disorders is TSH and creatinine levels. Higher TSH levels were significantly associated with the presence of sleep disorders. They reported that sleep disorders increased in hypothyroidism. ${ }^{[30]}$ In our study, no difference was detected between hypothyroidism and control group concerning EDS.

In a study with nine idiopathic hypersomnia patients defined by the International Classification of Sleep Disorders (ICSD-2) criteria, the effects of levothyroxine on longterm night sleep and EDS was investigated. In this study, patients diagnosed with hypothyroidism were excluded from the study. The patients' EDS was evaluated using ESS. After eight weeks of levothyroxine treatment, an improvement in the ESS scores of the patients was observed. ${ }^{[31]}$

In the study conducted with patients diagnosed with idiopathic hypersomnia defined by ICSD-2 criteria and diagnosed as subclinical hypothyroidism, an improvement in EDS and a decrease in the ESS scores were observed after eight weeks of levothyroxine treatment. ${ }^{[32]}$

In a study investigating sleep apnea syndrome in patients with hypothyroidism, 15 hypothyroid patients were evaluated with ESS. After stabilization of thyroid hormone status was achieved in patients, a significant improvement was observed in the ESS scores. ${ }^{[3]}$ Patients diagnosed with new-onset hypothyroidism were included in our study, but EDS was not evaluated after treatment.

In conclusion, in our study, in which we evaluated EDS in patients with hypothyroidism, there was no difference concerning EDS between the hypothyroidism and the control groups. Body weight, BMI, waist circumference, neck circumference, and triglyceride levels were higher and HDL cholesterol levels were lower in the hypothyroidism group than the control group. Patients with hypothyroidism and EDS had higher TC, LDL and lower HDL-c values than patients without EDS. Thyroid functions were normal and HDL-c level was found to be lower in the group with EDS. These results show us that EDS is progressing along with the deterioration in metabolic parameters. It was concluded that studies with wider participation should be conducted on this subject.

Ethics Committee Approval

Approved by the local ethics committee (date: $29 / 12 / 2016$, no: $|6-1|$ ).
Peer-review

Internally peer-reviewed.

Authorship Contributions

Concept: S.P.; Design: C.D., M.A.E.; Supervision: S.P., C.D.; Fundings: B.Ş.D., N.Ü., A.P.; Materials: N.Ü., A.P., Y,A,; Data: B.Ş.D., N.Ü., A.P.; Analysis: A.P., C.D.; Literature search: S.P., B.Ş.D.; Writing: S.P., B.Ş.D.; Critical revision: C.D., M.A.E.

Conflict of Interest

None declared.

\section{REFERENCES}

1. Sağlam F, Çakır B. Clinical Approach To Thyroid Diseases In Primary Health Care. Ankara MedicalJournal 2012;12:136-9.

2. Türkiye Endokrinoloji ve Metabolizma Derneği. Available at: http:// temd.org.tr/admin/uploads/tbl_kilavuz/201904261653402019tbl_ kilavuze72e4ddf38.pdf. Accessed Feb 11, 2020.

3. Vanderpump MP, Tunbridge WM. Epidemiology and prevention of clinical and subclinical hypothyroidism. Thyroid 2002;12:839-47.

4. Şen H, Dönderici Ö, Cengiz O, Cansaran S, Türker İ. Prevalence Of Subclinical Hypothyroidism In Dyslipidemic Patients. Turkiye Klinikleri J Med Sci 2007;27:344-9.

5. Arand D, Bonnet M, Hurwitz T, Mitler M, Rosa R, Sangal RB. The clinical use of the MSLT and MWT. Sleep 2005;28:123-44. [CrossRef]

6. Takenoshita S, Nishino S. Pharmacologic management of excessive daytime sleepiness. Sleep Med Clin 2017;12:461-78. [CrossRef]

7. Selvi Y, Kandeğer A, Sayın AA. Excessive Daytime Sleepiness. Current Approaches in Psychiatry 2016;8:114-32. [CrossRef]

8. Vgontzas AN, Legro RS, Bixler EO, Grayev A, Kales A, Chrousos GP. Polycystic ovary syndrome is associated with obstructive sleep apnea and daytime sleepiness: role of insülin resistance. J Clin Endocrinol Metab 2001;86:517-20. [CrossRef]

9. Fernandez-Mendoza J, Vgontzas AN, Kritikou I, Calhoun SL, Liao D, Bixler EO. Natural history of excessive daytime sleepiness: role of obesity, weightloss, depression, and sleep propensity. Sleep 2015;38:351-60. [CrossRef]

10. Barger LK, Lockley SW, Rajaratnam SM, Landrigan CP. Neurobehavioral, health, and safety consequences associated with shiftwork in safety-sensitive professions. Curr Neurol Neurosci Rep 2009;9:15564. [CrossRef]

11. Bixler EO, Vgontzas AN, Lin HM, Calhoun SL, Vela-Bueno A, Kales A. Excessive daytime sleepiness in a general population sample: the role of sleep apnea, age, obesity, diabetes, and depression. J Clin Endocrinol Metab 2005;90:4510-5. [CrossRef]

12. Grossi G, Perski A, Evengård B, Blomkvist V, Orth-Gomér K. Physiological correlates of burn out among women. J Psychosom Res 2003;55:309-16. [CrossRef]

13. Wilsmore BR, Grunstein RR, Fransen M, Woodward M, Norton $\mathrm{R}$, Ameratunga S. Sleep habits, insomnia, and daytime sleepiness in a large and healthy community-based sample of New Zealanders. J Clin Sleep Med 2013;9:559-66. [CrossRef]

14. Hayley AC, Williams LJ, Berk M, Kennedy GA, Jacka FN, Pasco JA. The relationship between excessive daytime sleepiness and depressive and anxiety disorders in women. Aust N Z J Psychiatry 2013;47:772-8. [CrossRef]

15. Hein M, Lanquart JP, Loas G, Hubain P, Linkowski P. Prevalence and risk factors of excessive daytime sleepiness in majör depression: a study with 703 individuals referred for polysomnography. J Affect Disord 2019;243:23-32. [CrossRef] 
16. Shen Y, Meng F, Tan SN, Zhang Y, Anderiescu EC, Abeysekera RE, et al. Excessive daytime sleepiness in medical students of Hunan province: Prevalence, correlates, and its relationship with suicidal behaviors. J Affect Disord 2019;255:90-5. [CrossRef]

17. Young T, Palta M, Dempsey J, Skatrud J, Weber S, Badr S. The occurrence of sleep-disordered breathing among middle age adults. $\mathrm{N}$ Engl J Med 1993;328:1230-5. [CrossRef]

18. Muşlu C, Baltacı D, Kutanis R, Kara İH. Quality of Life, Anxiety and Depression in NursesWorking at Primary Health Care and Hospitals. Konuralp Tip Dergisi 2012;4:17-23.

19. Ağargün MY, Çilli AS, Kara H, Bilici M, Telcioğlu M, Semiz ÜB, Başoğlu C. Epworth Uykululuk Ölçeği’nin geçerliği ve güvenirliği. Turk Psikiyatri Derg 1999;10:261-8.

20. Demir G. Daytime sleepiness and related factors in nursing students. Nurse Educ Today 2017;59:21-5. [CrossRef]

21. Johnson KM, Simon N, Wicks M, Barr K, O'Connor K, Schaad D. Amount of sleep, daytime sleepiness, hazardous driving, and quality of life of second year medical students. Acad Psychiatry 2017;41:669-73. [CrossRef]

22. Alzahrani JM, Aldossari KK, Abdulmajeed I, Alghamdi SH, Alshamrani AM, Alqahtani NS. Daytime sleepiness and academic performance among Arab medical students. Health Sci J 2016;10:1-5

23. Huang CF, Yang LY, Wu LM, Liu Y, Chen HM. Determinants of daytime sleepiness in first-year nursing students: a questionnaire survey. Nurse Educ Today 2014;34:1048-53. [CrossRef]

24. El Hangouche AJ, Jniene A, Aboudrar S, Errguig L, Rkain H, Cherti $\mathrm{M}$, et al. Relationship between poor quality sleep, excessive daytime sleepiness and low academic performance in medical students. Adv Med Educ Pract 2018;9:631-8. [CrossRef]
25. Machado-Duque ME, Echeverri Chabur JE, Machado-Alba JE. Excessive daytime sleepiness, poor quality sleep, and low academic performance in medical students. [Article in Spanish] Rev Colomb Psiquiatr 2015;44:137-42. [CrossRef]

26. Mirghani HO, Ahmed MA, Elbadawi AS. Daytime sleepiness and chronic sleep deprivation effects on academic performance among the Sudanese medical students. J Taibah Univ Med Sci 2015;10:467-70.

27. Pagnin D, de Queiroz V, Carvalho YT, Dutra AS, Amaral MB, Queiroz TT. The relation between burn out and sleep disorders in medical students. A Acad Psychiatry 2014;38:438-44. [CrossRef]

28. Zailinawati AH, Teng CL, Chung YC, Teow TL, Lee PN, Jagmohni KS. Daytime sleepiness and sleep quality among Malaysian medical students. Med J Malaysia 2009;64:108-10.

29. Johns MW. A new method for measuring daytime sleepiness: the Epworth sleepiness scale. Sleep 1991;14:540-5. [CrossRef]

30. Abassi MR, Safavi A, Haghverdi M, Saedi B. Sleep Disorders in ESRD Patients Undergoing Hemodialysis. Acta Med Iran 2016;54:176-84.

31. Shinno H, Ishikawa I, Yamanaka M, Usui A, Danjo S, Inami Y, et al. Effect of levothyroxine on prolonged nocturnal sleep time and excessive daytime somnolence in patients with idiopathic hypersomnia. Sleep Med 2011;12:578-83. [CrossRef]

32. Shinno H, Inami $Y$, Inagaki $T$, Kawamukai $T$, Utani E, Nakamura $Y$, et al. Successful treatment with levothyroxine for idiopathic hypersomnia patients with subclinical hypothyroidism. Gen Hosp Psychiatry 2009;31:190-3. [CrossRef]

33. Misiolek M, Marek B, Namyslowski G, Scierski W, Zwirska-Korczala K, Kazmierczak-Zagorska Z, et al. Sleep apnea syndrome and snoring in patients with hypothyroidism with relation to overweight. J Physiol Pharmacol 2007;58:77-85.

\section{Hipotiroidi Hastalarında Gündüz Aşırı Uykululuğunun Değerlendirilmesi}

Amaç: Bu çalışmadaki amacımız hipotiroidi tanısı almış hastalarda ve sağlıklı kontrol grubunda Epworth uykululuk ölçeğini kullanarak gündüz aşırı uykululuğunu araştırmaktır.

Gereç ve Yöntem: Yetmiş beşi hipotiroidi, 52'si kontrol grubu olmak üzere 127 kişi ile çalışma tamamlandı. Tüm katılımcıların yaş, boy, kilo, vücut kitle indeksi, bel çevresi, sistolik ve diyastolik kan basıncı kaydedildi. Tiroit hormon testleri ve biyokimyasal parametrelere sabah aç olarak bakıldı. Gündüz aşırı uykululuğu ölçmek için Epworth Uykululuk Ölçeği kullanıldı.

Bulgular: Epworth Uykululuk Ölçeği puanları hipotiroidili grupta $7.3 \pm 0.7$ kontrol grubunda ise $6.4 \pm 0.4$ olarak bulundu, gruplar arasında anlamlı farklılık yoktu $(p=0.703)$. Hipotiroidi olan grupta kontrol grubuna göre kilo $(p<0.00 \mathrm{I})$, vücut kitle indeksi $(p<0.00 \mathrm{I})$, bel çevresi $(p=0.00 \mathrm{I})$, trigliserit düzeyleri $(p=0.00 \mathrm{I})$ daha yüksek, yüksek yoğunluklu lipoprotein düzeyi daha düşük bulundu $(p=0.00 \mathrm{I})$. Hipotiroidi olup gündüz aşırı uykululuğu da olanlarda, gündüz aşırı uykululuğu olmayanlara göre total kolesterol, düşük yoğunluklu lipoprotein düzeyi daha yüksek, yüksek yoğunluklu lipoprotein düzeyi daha düşük bulundu. Tiroit fonksiyonları normal olup gündüz aşırı uykululuğu olan grupta da yüksek yoğunluklu lipoprotein düzeyi daha düşük bulundu. Epworth Uykululuk Ölçeği puanları ile yaş, kilo, boy, vücut kitle indeksi, bel çevresi, boyun çevresi, tiroit stimülan hormon, sistolik ve diyastolik kan basıncı ve kan lipit seviyeleri arasında ilişki tespit edilmedi ( $p>0.05$ ).

Sonuç: Hipotiroidi ve kontrol grubu gündüz aşırı uykululuğu yönünden benzer bulundu. Ancak gündüz aşırı uykuluğu olan grupta, olmayan gruba göre metabolik parametrelerde bozulma tespit edildi. Hipotiroidi hastalarında gündüz aşırı uykululuğunun daha geniş katılımlı benzer çalışmalarla değerlendirilmesi gerektiği sonucuna varıldı.

Anahtar Sözcükler: Epworth Uykuluk Ölçeği; gündüz aşırı uykuluğu; hipotiroidi. 